Огляди літератури, оригінальні дослідження, погляд на проблему, ювілеї

УДК 616.12-008.331.1-06:616-056.52-053.9

DOI 10.11603/1811-2471.2018.v0.i2.8930

\title{
ОСОБЛИВОСТІ ПЕРЕБІГУ АРТЕРІАЛЬНОÏ ГІПЕРТЕНЗІЇ У ХВОРИХ ПОХИЛОГО ВІКУ В УМОВАХ КОМОРБІДНОСТІ З ОЖИРІННЯМ
}

\author{
๑Н. І. Ярема, І. П. Савченко, Л. В. Наумова, О. І. Коцюба, Н. М. Вівчар, \\ Н. А. Головач, Л. Ю. Орищин, В. М. Зубанюк
}

ДВНЗ «Тернопільський державний медичний університет імені І. Я. Горбачевського МОЗ України»

РЕЗЮМЕ. Проведено вивчення впливу ожиріння на добовий профіль артеріального тиску (АТ) у осіб похилого віку. У людей похилого віку з ожирінням при ДМАТ реєструються більш високі денні, нічні і середньодобові показники АТ, ніж у хворих без ожиріння, та виявлено вищі показники навантаження тиском для систолічного і діастолічного АТ. У пацієнтів з ожирінням частіше виявляють несприятливі типи циркадного профілю АТ. Андроїдне ожиріння у хворих похилого віку пов'язане з більш високими цифрами систолічного, діастолічного і пульсового АТ та показниками навантаження тиском, порівняно з пацієнтами із гіноїдним типом ожиріння.

КлючОВІ СлОВА: ожиріння; артеріальна гіпертензія; добовий профіль артеріального тиску; похилий вік.

Вступ. Ожиріння, як відомо, $є$ одним із основних і незалежних факторів ризику (ФР) розвитку серцево-судинних захворювань i, зокрема, артеріальної гіпертензії $[1,2]$. Тому зростання числа людей з надмірною масою тіла і ожирінням залишається однією з важливих міждисциплінарних проблем [3]. Виявлено, що артеріальна гіпертензія (АГ) при ожирінні зустрічається в 6 разів частіше, ніж при нормальній масі тіла [4]. Збільшення маси жирової тканини на 10 \% призводить до збільшення АТ на 6/4 мм рт. ст. $[5,6]$. Залежність між ожирінням і АГ була підтверджена у Фремінгемському дослідженні, яке показало, що із збільшенням маси тіла значно збільшується поширеність АГ у різних вікових групах населення $[7,8]$.

За офіційними даними Центру медичної статистики МОЗ, станом на 01.01.2014 в Україні зареєстровано 12153040 хворих на АГ, що становить близько третини дорослого населення. Поширеність АГ в осіб пенсійного віку перевищує середній показник в 1,8 раза і становить 60014,7 на 100 тис. населення. У 2013 році було зареєстровано 6873121 осіб похилого віку з АГ [9, 10]. Ризик виникнення ускладнень та смерті при АГ зростає відповідно до числа супутніх ФР. В українській популяції, за результатами досліджень, проведених співробітниками ННЦ «Інститут кардіології імені академіка М. Д. Стражеска» НАМН України, лише $1 \%$ пацієнтів з підвищеним АТ не має додаткових факторів ризику (ФР), у кожного восьмого пацієнта АГ поєднується з одним, у кожного четвертого - з двома, у 61 \% пацієнтів - з трьома і більше ФР. Тому контроль маси тіла (МТ) як одного 3 основних ФР рекомендується всім пацієнтам з АГ, особливо у старшій віковій групі. Слід підтримувати індекс МТ в межах 18,5-24,9 кг/м², окружність талії (ОТ) $\leq 88$ см у жінок, $\leq 102$ см у чоловіків [4].

Низка досліджень була присвячена вивченню взаємозв'язків ожиріння та АГ, проте з акцен- том на пацієнтах працездатного віку. У зв'язку з цим, метою даного дослідження стало вивчення добового профілю АТ та виявлення його взаємозв'язків з надмірною масою тіла та ожирінням у пацієнтів похилого віку.

Матеріали і методи дослідження. У дослідження були включені 78 осіб похилого віку (6075 років). Після вимірювання зросту і МТ з подальшим розрахунком індексу маси тіла (IMT), відповідно до критеріїв ВООЗ (2000), 56 хворих (30 жінок і 26 чоловіків) на АГ склали основну (I) групу, оскільки мали ожиріння різного ступеня вираженості (IMT $\left.\geq 30 \mathrm{kr} / \mathrm{M}^{2}\right)$. У решти пацієнтів (22 особи - 12 жінок і 10 чоловіків) не було ожиріння, тобто вони мали або нормальну МТ, або надмірну вагу, і склали контрольну (II) групу (IMT $\leq 29,9$ кг/м²). Крім визначення ІМТ, антропометричні дослідження включали вимірювання окружності талії, стегон і відношення окружності талії до окружності стегон, як показників, що визначають тип розподілу жирової тканини. Добове моніторування АТ (ДМАТ) проводили всім пацієнтам протягом 22-24 годин за допомогою кардіомонітора «Кардіотехніка-4000 АД" виробництва ЗАО «Інкарт» (Санкт-Петербург), відповідно до вимог Американської асоціації ДМАТ $[11,12]$. Інтервал між вимірюваннями АТ у денний час дорівнював 15 хв (з 6 до 22 год), у нічний - 30 хв (з 22 до 6 год). Проводили корекцію тимчасових інтервалів активного і пасивного періодів з урахуванням розпорядку дня кожного конкретного пацієнта, при цьому некоректні вимірювання виключили під час попередньої обробки даних. Успішними вважали дослідження при більш ніж 50 якісних вимірювань впродовж доби. Аналізували середні цифри систолічного АТ (САТ), діастолічного АТ (ДАТ) і пульсового АТ (пАТ) за денний і нічний періоди, індекси часу гіпертензії і ступінь нічного зниження АТ. 
Огляди літератури, оригінальні дослідження, погляд на проблему, ювілеї

Статистичний аналіз результатів проводили за допомогою пакета прикладних програм "STATISTICA for Windows», версія 6.0 із використанням непараметричних методів статистики. Дані представлені у вигляді $(\mathrm{M} \pm \mathrm{m})$, відмінності вважали достовірними при $(p<0,05)$. Оцінку статистичної достовірності відмінностей вибірок проводили з використанням U-критерію МаннаУїтні та за допомогою кореляційного аналізу з визначенням коефіцієнта лінійної кореляції Пірсона.

Результати й обговорення. Середній вік пацієнтів у групі з ожирінням і у контрольній групі достовірно не відрізнявся, складаючи $(67,15 \pm 3,24)$ р. в групі без ожиріння і $(68,22 \pm 4,05)$ р. в групі з ожирінням. Також не було істотних відмінностей за тривалістю АГ в анамнезі при порівнянні обох груп. Тривалість анамнезу АГ коливалася від 13 до 28 років і склала $(16,55 \pm 3,47)$ р. в групі без ожиріння і $(17,78 \pm 2,62)$ р. в групі з ожирінням. В I групі хворих достовірно вищими були значення окружності талії, що відображають вісцеральне накопичення жирової тканини, складаючи в середньому $(103,36 \pm$ $7,68)$ см, порівняно з $(81,52 \pm 6,75)$ см у II групі $(p<0,01)$. Відношення окружності талії до окружності стегон, збільшення якого (індекс $>0,90$ у чоловіків і >0,80-0,82 у жінок) свідчить про перерозподіл жирової тканини за несприятливим, «андроїдним» типом, в середньому також було вище в I групі, складаючи $(0,98 \pm 0,04)$, порівняно з $(0,80 \pm$ $0,02)$ в II групі $(p<0,05)$. Аналіз даних ДМАТ показав, що у пацієнтів з ожирінням вдень, вночі і загалом за добу середні цифри САТ і ДАТ достовірно вищі, ніж у пацієнтів без ожиріння. За результатами низки досліджень виявлено, що середні значення АТ за добу тісно корелюють з ураженням органів-мішеней і прогнозом при АГ [13]. У І групі хворих були достовірно вищі індекси часу гіпертензії для САТ і ДАТ за всі періоди. Для показників пАТ не було виявлено достовірних відмінностей (табл. 1).

Таблиця 1. Показники добового моніторування АТ у обстежуваних пацієнтів

\begin{tabular}{|c|c|c|}
\hline Показник & І група, n=56 & II група, n=22 \\
\hline CAT $_{\text {доб. сер., }}$ MM PT. СT & $146,66 \pm 3,67$ & $134,67 \pm 2,59^{* *}$ \\
\hline ДАТ & $83,21 \pm 3,48$ & $71,10 \pm 2,37^{*}$ \\
\hline пАТ & $63,52 \pm 2,79$ & $60,44 \pm 2,55$ \\
\hline CAT ден. сер., МM РТ. СТ. & $149,52 \pm 4,84$ & $137,97 \pm 3,40^{*}$ \\
\hline 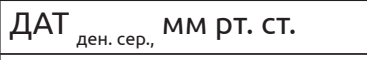 & $86,38 \pm 3,75$ & $74,72 \pm 3,76^{* *}$ \\
\hline пАТ & $63,34 \pm 2,04$ & $63,31 \pm 2,96$ \\
\hline CAT ${ }_{\text {ніч. сер., }}$ MM РТ. СТ. & $132,03 \pm 2,97$ & $123,21 \pm 3,40^{*}$ \\
\hline ДАТ ${ }_{\text {нiч. сер., }}$ ММ РТ. СТ. & $78,03 \pm 2,12$ & $65,18 \pm 1,51^{*}$ \\
\hline пAТ ${ }_{\text {ніч. сер., }}$ МM рт. Ст. & $63,97 \pm 2,61$ & $65,77 \pm 2,48$ \\
\hline Індекс часу САТ & $54,28 \pm 1,10$ & $34,43 \pm 1,99 * *$ \\
\hline Індекс часу ДАТ & $25,45 \pm 1,59$ & $11,23 \pm 1,06^{*}$ \\
\hline Індекс часу САТ ден., \% & $47,79 \pm 1,27$ & $33,26 \pm 1,88^{*}$ \\
\hline Індекс часу ДАТ & $23,76 \pm 1,58$ & $12,21 \pm 1,42^{* *}$ \\
\hline Індекс часу САT & $64,76 \pm 3,88$ & $40,92 \pm 3,12^{* *}$ \\
\hline Індекс часу ДАТ & $31,59 \pm 1,27$ & $14,97 \pm 1,01^{*}$ \\
\hline
\end{tabular}

Примітка. Достовірність відмінностей різниці показників у пацієнтів I (основної) групи і ІІ (контрольної) груп: * - p<0,05; ** - p<0,01.

Критеріями нормального добового рівня АТ, за даними ДМАТ, вважають 130/80 мм рт. ст. для середнього АТ за добу, 135/85 мм рт. ст. - для середнього АТ вдень і 120/70 мм рт. ст. - для середнього АТ вночі [2]. Згідно з цим, в I групі хворих денний САТ був підвищений у 32 пацієнтів (57,14\%), вночі - у 38 (67,86 \%), в цілому за добу у 34 пацієнтів (60,71\%). У II групі частка пацієнтів з підвищеним АТ була майже в 2 рази менше. Так, САТ був підвищеним вдень у 6 пацієнтів $(27,27 \%)$, вночі - у 8 (36,36 \%) і за добу в цілому - у 8 хворих
(36,36 \%) контрольної групи. Для пацієнтів похилого віку характерний розвиток ізольованої систолічної АГ $[14,15]$. За даними нашого дослідження, підвищення ДАТ виявлялося також значно рідше, ніж САТ. В I групі ДАТ вдень був підвищеним у 8 пацієнтів (14,28 \%), вночі - у 14 (25\%), за добу в цілому - у 10 (17,86 \%). Частка пацієнтів із підвищеним ДАТ в II групі була майже вдвічі меншою: ДАТ був підвищеним вдень у 2 пацієнтів (9,09 \%), вночі - у 4 (18,18 \%) і в цілому за добу -у 4 хворих $(18,18 \%)$ контрольної групи. 
Огляди літератури, оригінальні дослідження, погляд на проблему, ювілеї

Характерною ознакою АГ у літніх пацієнтів $\epsilon$ висока варіабельність АТ, особливо САТ [14]. Тому у хворих похилого віку доцільне застосування індексу часу гіпертензії для оцінки «навантаження тиском». В I групі індекс часу гіпертензії для САТ був підвищеним вдень у 38 пацієнтів $(67,86 \%)$, вночі - у 44 (78,57 \%), за добу - у 42 (75\%). У II групі цей показник був практично у 2 рази нижчим. Індекс часу гіпертензії САТ був підвищений вдень у 8 пацієнтів (36,36\%), вночі - у 10 (45,45\%), за добу - у 10 (45,45 \%) осіб II групи. Підвищення індексу часу гіпертензії ДАТ реєстрували рідше. IHдекс часу гіпертензії для ДАТ був підвищеним вдень у 10 хворих (17,85\%), вночі - у 12 (21,43\%), за добу в цілому - у 10 пацієнтів $(17,85 \%)$ основної групи. Підвищення цього параметра в II групі виявляли в 2,3 раза рідше, ніж в основній.

Достатнє зниження як САТ, так і ДАТ (тип «dippers») у групі з ожирінням реєстрували достовірно рідше, ніж у пацієнтів без ожиріння $(p<0,05)$. В I групі переважали хворі з недостатнім нічним зниженням АТ (тип «nondipper»), тоді як у II групі частка хворих з достатнім зниженням АТ була вищою (рис. 1). Як відомо, відсутність достатнього зниження АТ у нічні години пов'язана з більш високим ризиком розвитку серцево-судинних ускладнень [16].

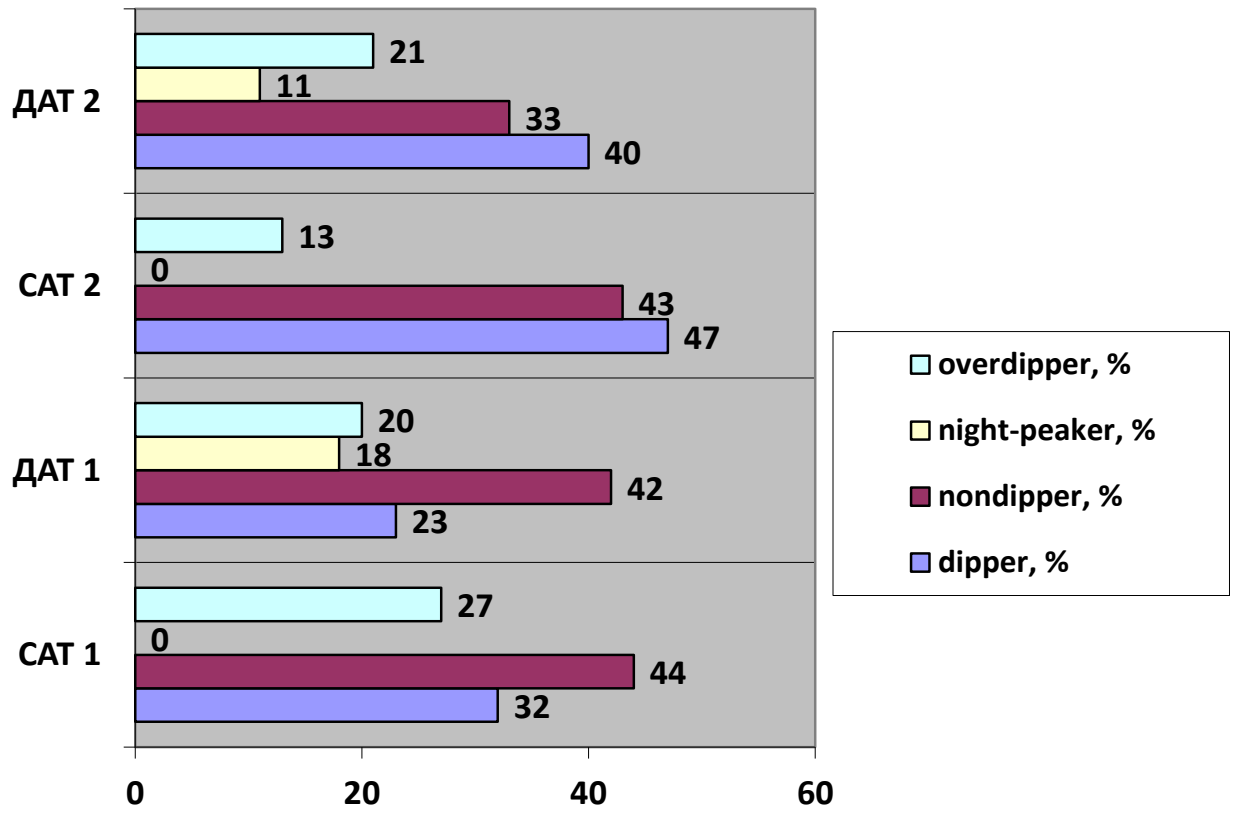

Рис. 1. Розподіл пацієнтів з ожирінням (САТ1 і ДАТ1) і без ожиріння (САТ2 і ДАТ2) залежно від типу добової динаміки АТ.

У I групі частка пацієнтів з надмірним зниженням САТ вночі (тип «оverdipper») була достовірно вищою, ніж в II групі $(p<0,05)$. Надмірне зниження АТ у нічні години пов'язують з гіпоперфузією головного мозку і міокарда, особливо при зниженні коронарного резерву [15]. В обох групах були виявлені пацієнти з підвищенням ДАТ в нічні години (тип «night-peaker»), проте в I групі частка таких хворих була достовірно вищою $(p<0,05)$.

У рекомендаціях Міжнародної групи ВООЗ з ожиріння (2016) зазначено, що не тільки ожиріння як таке, але і тип перерозподілу жирової тканини в організмі $\epsilon$ важливим фактором розвитку АГ. Несприятливим вважають андроїдне (вісцеральне) ожиріння, що характеризується накопиченням жирової тканини в ділянці передньої черевної стінки і оцінюється за величиною окружності талії [17, 18]. Ми порівняли пацієнтів I групи з андроїдним ожирінням (32 осіб) і без нього (24 пацієнти з гіно- їдним типом ожиріння). Аналіз отриманих даних показав, що середні цифри не тільки САТ і ДАТ, але і пАТ вночі і за добу в цілому у хворих з андроїдним ожирінням достовірно вищі. Пульсовий АТ відображає еластичність стінок великих судин, і з його збільшенням понад 53 мм рт. ст. зростає ризик розвитку судинних подій [16]. У підгрупі без андроїдного ожиріння середній рівень вночі САТ склав $(124,3 \pm 4,46)$ мм Рт. СТ., ДАТ - $(68,2 \pm 1,12)$ Мм РТ. СТ., пАТ - $(57,7 \pm 1,53)$ мм рт. ст., у підгрупі з андроїдним ожирінням, відповідно, $(157,5 \pm 3,81)(p<0,05) ;(81,3 \pm$ $2,82)(p<0,05)$ i $(69,8 \pm 2,14)$ мм рт. ст. $(p<0,01)$. Середнє значення за добу САТ у пацієнтів без андроїдного ожиріння склало $(134,1 \pm 4,62)$ мм рт. ст., ДАТ $(73,4 \pm 1,02)$ мм рт. СТ., пАТ - $(58,7 \pm 1,48)$ мм рт. ст., У хворих 3 андроїдним ожирінням, відповідно, $(150,2 \pm 4,41)(p<0,05)$; $(78,4 \pm 1,87)(p<0,05)$ i $(66,23 \pm$ $1,65)$ мм рт. ст. $(p<0,05)$. Індекси часу гіпертензії для САТ і ДАТ були достовірно вищими у пацієнтів з ан- 
Огляди літератури, оригінальні дослідження, погляд на проблему, ювілеї дроїдним ожирінням. Аналіз отриманих результатів показав, що у пацієнтів похилого віку існує взаємозв'язок показників ДМАТ з андроїдним типом перерозподілу жирової тканини, який спричиняє негативний вплив на показники АТ.

Висновки. У людей похилого віку з ожирінням при ДМАТ реєструються більш високі денні, нічні і середньодобові показники як САТ, так і ДАТ,

порівняно з хворими без ожиріння; у них виявлено вищі показники навантаження тиском для САТ і ДАТ. Несприятливі типи циркадного профілю АТ частіше виявляють у пацієнтів з ожирінням. Андроїдне ожиріння у хворих похилого віку пов'язане з більш високими цифрами САТ, ДАТ, пАТ і показниками навантаження тиском, порівняно з пацієнтами з гіноїдним типом ожиріння.

\section{ЛІТЕРАТУРА}

1. Hajer G. R. Adipose tissue dysfunction in obesity, diabetes, and vascular diseases / G. R. Hajer, T. W. Van Haeften, F. L. J. Visseren // Europ. Heart. J. - 2008. - No. 29. P. 2959-2971.

2. Sander G. E. High blood pressure in the geriatric population: treatment consideration / G. E. Sander // Amer. J. Geriat. Cardiol. - 2002. - No. 11 (3). - P. 223-232.

3. Фадеенко Г. Д. Ожирение и риск сердечно-сосудистых заболеваний / Г. Д. Фадеенко, А. Е. Гриднев // Ліки України. - 2009. - № 7. - С. 55-64.

4. Сердечно-сосудистые заболевания и контроль факторов риска // Діабет. Ожиріння. Метаболічний синдром. - 2016. - № 1. - С. 15-30.

5. Haffner S. M. Metabolic predictors of hypertension / S. M. Haffner // Hypertension. - 2002. - No. 17 (3). P. 23-28.

6. Фадєєнко Г. Д. Можливості прогнозування і профілактики розвитку коморбідності серцево-судинних захворювань і цукрового діабету 2 типу в популяції осіб підвищеного кардіоваскулярного ризику / Г. Д. Фадєєнко, А. О. Несен, О. В. Бабенко //Український терапевтичний журнал. - 2016. - № 2. - С.14-21.

7. Профілактика серцево-судинних захворювань: історичний аспект та сучасний стан проблеми (Частина 1) / І. М. Гідзинська, Г. З. Мороз, Т. С. Ласиця, О. О. Дзізінська // Тhегаріа. Український медичний вісник. 2015. - № 6 (99). - С. 62-64.

8. Кваша Е. А. Влияние ибыточной массы тела на смертность женщин от сердечно-сосудистых заболеваний: данные проспективного исследования / Е. А. Кваша//Український кардіологічнийжурнал. -2012.-№2.C. $70-73$.

9. Уніфікований клінічний протокол первинної, екстреної та вторинної (спеціалізованої) медичної допомоги «Артеріальна гіпертензія», 2016

10. Уніфікований клінічний протокол первинної медичної допомоги. Профілактика серцево-судинних

\section{REFERENCES}

1. Hajer, G.R., van Haeften, T.W., \& Visseren, F.L.J. (2008). Adipose tissue dysfunction in obesity, diabetes, and vascular diseases. Europ. Heart. J., 29, 2959-2971.

2. Sander, G.E. (2002). High blood pressure in the geriatric population: treatment consideration. Amer. J. Geriat. Cardiol., 11 (3), 223-232.

захворювань // Бібліотека сімейного лікаря та сімейної медсестри. - 2016. - № 3. - С. 36-65.

11. Ахунова С. Практические аспекты метода суточного мониторирования артериального давления / С. Ахунова, И. Кирилюк / Практическая медицина. 2011. - № 3. - С. 104-112.

12. Игнатенко Т. С. Циркадный ритм артериального давления у больных хроническим гломерулонефритом с сердечно-сосудистыми нарушениями / Т. С. Игнатенко // Кровообіг та гемостаз. - 2010. - № 3. - С. 38-41.

13. Агаев А. А. Влияние избыточной массы тела на уровень артериального давления у пациентов с артериальной гипертонией и сердечно-сосудистыми заболеваниями / А. А. Агаев, М. К. Мустафаев // Международный медицинский журнал. - 2009. - № 4. - С. 38-41.

14. Алиджанова Х. Г. Старение, возрастзависимые болезни и некоторые факторы риска сердечно-сосудистых заболеваний у лиц пожилого и старческого возраста / Х. Г. Алиджанова, Б. А. Кауров // Клиническая медицина. - 2011. - Т. 89, № 3. - С. 21-27.

15. Rodrhguez C. Chronobiological profi le of arterial blood pressure and heart rate in a family group determined by automatic monitoring / C. Rodrhguez, M. A. Revilla, M. Revilla // Gac. Med. Mex. - 2003. - No. 134 (1). - P. 15-26.

16. Verdecchia P. Reference values for ambulatory blood pressure and self-measured blood pressure based on prospective outcome data / P. Verdecchia // Blood Press. Monit. - 2001. - Vol. 6, No. 6. - P. 323-327.

17. Mozaffarian D. Диета и приоритеты рекомендаций при сердечно- сосудистых заболеваниях, диабете и ожирении. Обзор литературы /D. Mozaffarian // Діабет. Ожиріння. Метаболічний синдром. - 2016. - № 3. - С. 21-39.

18. Mozaflarian D. Диета и приоритеты рекомендаций при сердечно- сосудистых заболеваниях, диабете и ожирении. Обзор литературы / D. Mozaflarian // Діабет. Ожиріння. Метаболічний синдром. - 2016. - № 4. - С. 18-34. 
Огляди літератури, оригінальні дослідження, погляд на проблему, ювілеї

of risk factors]. Diabet. Ozhyrinnia. Metabolichnyi syndrom Diabetes. Obesity. Metabolic Syndrome, 1, 15-30 [in Russian].

5. Haffner, S.M. (2002). Metabolic predictors of hypertension. Hypertension, 17 (3), 23-28.

6. Fadieienko, H.D., Nesen, A.O., \& Babenko, O.V. (2016). Mozhlyvosti prohnozuvannia i profilaktyky rozvytku komorbidnosti sertsevo-sudynnykh zakhvoriuvan i tsukrovoho diabetu 2 typu v populiatsii osib pidvyshchenoho kardiovaskuliarnoho ryzyku [The possibilities of forecasting and prevention of development of comorbidity of cardiovascular diseases and type 2 diabetes mellitus in the population of persons with increased cardiovascular risk]. Ukrainskyi terapevtychnyi zhurnal - Ukrainian Therapeutic Journal, 2, 14-21 [in Ukrainian].

7. Hidzynska, I.M., Moroz, H.Z., Lasytsia, T.S., \& Dzizinska, O.O. (2015). Profilaktyka sertsevo-sudynnykh zakhvoriuvan: istorychnyi aspekt ta suchasnyi stan problemy (Chastyna 1) [Prevention of cardiovascular diseases: historical aspect and current state of problems (Part 1)]. "Therapiia. Ukrainskyi medychnyi visnyk" - "Therapy. Ukrainian Medical Bulletin", 6 (99), 62-64 [in Ukrainian].

8. Kvasha, E.A. (2012). Vliyanie izbytochnoy massy tela na smertnost zhenshchin ot serdechno-sosudistykh zabolevaniy: dannye prospektivnogo issledovaniya [The influence of excess body weight on the mortality of women on cardiovascular diseases: evidence from a prospective study]. Ukrainskyi kardiolohichnyi zhurnal - Ukrainian Cardiological Journal, 2, 70-73 [in Russian].

9. (2016). Unifikovanyi klinichnyi protokol pervynnoi, ekstrenoi ta vtorynnoi (spetsializovanoi) medychnoi dopomohy "Arterialna hipertenziia" [Unified clinical protocol for primary, emergency and secondary (specialized) medical aid "Arterial hypertension"]. [in Ukrainian].

10. (2016). Unifikovanyi klinichnyi protokol pervynnoi medychnoi dopomohy. Profilaktyka sertsevo-sudynnykh zakhvoriuvan [Unified clinical protocol for primary care. Prevention of cardiovascular diseases]. Biblioteka simeinoho likaria ta simeinoi medsestry-Family Doctor's and Family Nurse's Library, 3, 36-65 [in Ukrainian].

11. Akhunova, S., \& Kirilyuk, I. (2011). Prakticheskie aspekty metoda sutochnogo monitorirovaniya arterialnogo davleniya [Practical aspects of the method of daily monitoring of blood pressure]. Prakticheskaya meditsynaPractical Medicine, 3, 104-112 [in Russian].
12. Ignatenko, T.S. (2010). Tsirkadnyy ritm arterialnogo davleniya u bolnykh khronicheskim khlomerulonefritom $\mathrm{s}$ serdechno-sosudistymi narusheniyami [Circadian rhythm of arterial pressure in patients with chronic glomerulonephritis with cardiovascular disorders]. Krovoobih ta hemostaz - Blood Circulation and Hemostasis, 3, 38-41 [in Russian].

13. Agayev, A.A., \& Mustafayev, M.K. (2009). Vliyaniye izbitochnoy massy tela na uroven arterialnogo davleniya u patsyyentov s arterialnoy gipertoniyey i serdechno-sosudistymi zabolevaniyamy [Influence of excess body weight on blood pressure level in patients with arterial hypertension and cardiovascular diseases]. Mezhdunarodnyy meditsynskiy zhurnal - International Medical Journal, 4, 3841 [in Russian].

14. Alidzhanova, Kh.G., \& Kaurov, B.A. (2011). Stareniye, vozrastzavysymye bolezni i nekotorye faktory riska serdechno-sosudystykh zabolevaniy u lits pozhylogo i starcheskogo vozrasta [Aging, age-dependent diseases and some risk factors for cardiovascular diseases in persons of the elderly and old age]. Klinicheskaya meditsynaClinical Medicine, 3 (89), 21-27 [in Russian].

15. Rodrhguez, C., Revilla, M.A., \& Revilla, M. (2003). Chronobiological profile of arterial blood pressure and heart rate in a family group determined by automatic monitoring. Gac. Med. Mex., 134 (1), 15-26.

16. Verdecchia, P. (2001). Reference values for ambulatory blood pressure and self-measured blood pressure based on prospective outcome data. Blood Press. Monit., 6 (6), 323-327.

17. Mozaffaryan, D. (2016). Diyeta i prioritety rekomendatsiy pri serdechno-sosudistykh zabolevaniyakh, diabete i ozhirenii. Obzor literatury [Diet and recommendations priorities for cardiovascular diseases, diabetes and obesity. Review of the literature]. Diabet. Ozhyrinnia. Metabolichnyi syndrom - Diabetes. Obesity. Metabolic Syndrome, 3, 21-39 [in Russian].

18. Mozaflaryan, D. (2016). Diyeta i prioritety rekomendatsiy pri serdechno-sosudistykh zabolevaniyakh, diabete i ozhirenii. Obzor literatury [Diet and priorities of recommendations for cardiovascular diseases, diabetes and obesity. Review of the literature]. Diabet. Ozhyrinnia. Metabolichnyi syndrom - Diabetes. Obesity. Metabolic Syndrome, 4, 18-34 [in Russian].

\title{
ОСОБЕННОСТИ ТЕЧЕНИЯ АРТЕРИАЛЬНОЙ ГИПЕРТЕНЗИИ У БОЛЬНЫХ ПОЖИЛОГО ВОЗРАСТА В УСЛОВИЯХ КОМОРБИДНОСТИ С ОЖИРЕНИЕМ
}

\author{
○Н. И. Ярема, И. П. Савченко, Л. В. Наумова, О. И. Коцюба, Н. М. Вівчар,
} Н. А. Головач, Л. Ю. Орищин, В. Н. Зубанюк

\author{
ГВуз «Тернопольский государственный медицинский университет имени И. Я. Горбачевского \\ МЗ Украины»
}

РЕЗЮМЕ. Проведено изучение влияния ожирения на суточный профиль артериального давления (АД) у пациентов пожилого возраста. У лиц пожилого возраста с ожирением при СМАД регистрируются более высокие дневные, ночные и суточные показатели АД, чем у больных без ожирения, а также выявлены более высокие показатели нагрузки давлением для систолического и диастолического АД. У пациентов с ожирением чаще 
Огляди літератури, оригінальні дослідження, погляд на проблему, ювілеї

выявляют неблагоприятные типы суточного профиля АД. Андроидное ожирение у лиц пожилого возраста связано с более высокими цифрами систолического, диастолического и пульсового АД, а также показателями нагрузки давлением, в сравнении с пациентами с гиноидным ожирением.

КЛЮчЕВЫЕ СЛОВА: ожирение; артериальная гипертензия; суточный профиль артериального давления; пожилой возраст.

\section{FEATURES OF ARTERIAL HYPERTENSION DISEASE IN PATIENTS OF ELDERLY AGE IN CONDITIONS OF COMORBIDITY WITH OBESITY}

\section{@N. I. Yarema, I. P. Savchenko, L. V. Naumova, O. I. Kotsyuba, N. M. Vivchar,} N. A. Golovach, L. Y. Oryshchyn, V. M. Zubanyuk

\section{Horbachevsky Ternopil State Medical University}

SUMMARY. The study of the effect of excess body weight and obesity on the daily blood pressure profile (BP) in the elderly was conducted. In obese elderly patients with daily blood pressure monitoring, higher daily, night and average daily BP values are recorded compared with patients without obesity, and higher values for both systolic and diastolic blood pressure for elderly obese. In obese patients, adverse type of circadian BP profile is more often detected. Android obesity in elderly patients is associated with higher numbers of systolic, diastolic and pulsatile BP and pressure index compared to patients with a hyoid type of obesity.

KEY WORDS: obesity; arterial hypertension; daily blood pressure profile; elderly age. 